Article

\title{
Populists and Technocrats in Latin America: Conflict, Cohabitation, and Cooperation
}

\author{
Rodrigo Barrenechea ${ }^{1}$ and Eduardo Dargent ${ }^{2, *}$ \\ ${ }^{1}$ Weatherhead Center for International Affairs, Harvard University, Cambridge, MA 02138, USA; \\ E-Mail: rbarrenechea@pucp.edu.pe \\ ${ }^{2}$ Social Science Department, Pontificia Universidad Católica del Perú, 15088 Lima, Peru; E-Mail: edargent@pucp.edu.pe \\ * Corresponding author
}

Submitted: 10 June 2020 | Accepted: 31 August 2020 | Published: 17 December 2020

\begin{abstract}
The literature frequently presents populists and technocrats as antagonistic. Although undoubtedly there are good historical examples that confirm this tension, in this article we propose that the relations between economic technocrats and populists are less conflictive than usually assumed and cohabitation a more common outcome than expected. We argue that two conditions moderate conflict between populists and economic technocrats, leading not only to their cohabitation but to cooperation between them: the programmatic mandate of populists and the economic context of their rise to power. We analyse the relations of economic experts with nine populist presidents in contemporary Latin America to show this argument's soundness.
\end{abstract}

\section{Keywords}

Latin America; political economy; populism; technocrats

Issue

This article is part of the issue "Varieties of Technocratic Populism around the World" edited by Petra Guasti (Institute of Sociology of the Czech Academy of Sciences, Czech Republic) and Lenka Buštíková (Institute of Sociology of the Czech Academy of Sciences, Czech Republic / Arizona State University, USA).

(C) 2020 by the authors; licensee Cogitatio (Lisbon, Portugal). This article is licensed under a Creative Commons Attribution 4.0 International License (CC BY).

\section{Introduction}

Populists and technocrats are archetypical political actors in Latin America. Myriad authors have studied the relevance and power of leaders who garner widespread support and rule in the name of 'the people's' will. Juan Peron in Argentina, Getulio Vargas in Brazil, and more recently, Hugo Chávez in Venezuela are all examples of this political animal in the region. At the same time, high-ranking policymakers who claim to adopt and conduct policies in the name of technical rationality have also attracted significant academic attention. Be it Money Doctors in the Andes or Chicago, Boys in Chile, experts, and especially economic experts have also shaped their polities in meaningful ways (Centeno \& Silva, 1998; Dargent, 2020). Given the long history of these actors in the region, instead of focusing on technocratic populists, as have other contributions to this thematic issue, here we analyse the conditions under which populists and economic technocrats engage in conflict, cohabitate, and even cooperate in Latin America.

The literature frequently presents populists and technocrats as antagonistic. Daniele Caramani, for example, proposes populism and technocracy as alternative ideal forms to party democracy, with "populism stressing the centrality of a putative will of the people in guiding political action and technocracy stressing the centrality of rational speculation in identifying both the goals of a society and the means to implement them" (Caramani, 2017, p. 54). Caramani also highlights the commonalities between these ideal forms as examples of "unmediated politics... between a supposedly unitary and common 
interest of society on the one hand and elites on the other," which helps to understand why populists can also exploit technical objective knowledge to attain popular legitimacy (Buštíková \& Guasti, 2019; de la Torre, 2013; Guasti \& Buštíková, 2020). Nonetheless, it is more common that in their quest to respond to the will of 'the people' populists clash with technical and scientific recommendations from policy experts.

Are populists and experts inherently opposed? In Latin America, this question often takes a more specific form and focuses on economic technocrats. Economic technocrats usually are equated with orthodox economists promoting neoliberal policies and as being antagonistic to left-wing policies. We do not follow this approach. It is a mistake to equate orthodoxy with expertise; the region provides numerous examples of heterodox economic technocrats. In this article, economic experts can be orthodox or heterodox, but to be powerful, they must have control over economic policy; in particular, assure a balanced public deficit that proves they are capable of limiting populist leaders' profligate use of public funds to advance political goals. Some scholars studying Latin America even resort to the notion of "economic populism" to refer to a tendency among populist presidents and leaders to engage in unrestricted spending, with little regard for technical and fiscal limits, often leading to inflationary cycles (Acemoglu, Egorov, \& Sonin, 2013; Dornbusch \& Edwards, 1991; Sachs, 1989).

In answering this question, it is critical to understand who can be considered a populist politician and a technocrat. Building on Levitsky and Loxton (2013), we define populist politicians as those who mobilize support through anti-establishment appeals, who are typically outsiders to the political system, and who tend to reject the intermediation and controls from liberal democratic institutions by claiming to represent 'the will of the people.' These anti-establishment appeals in the case of classical populism were directed against elites, the rich, or the powerful, those preventing the people from participating in politics and improving their standard of living. More recently, as discussed by Weyland, populists have directed their criticisms towards the political establishment represented by ossified political parties or partidocracia (Weyland, 2001, 2003). As discussed below, depending on the type of social demands being addressed by populists, these discourses could adopt a left-wing or right-wing discourse.

Technocrats, on the other hand, are distinguished from other political actors by their higher level of expertise certified by their specialized academic training (Centeno \& Silva, 1998, p. 2; Williams, 2006, p. 119). David Collier's classic definition captures this characteristic of technocrats: "Individuals with a high level of specialized academic training which serves as a principal criterion on the basis of which they are selected to occupy key decision-making or advisory roles in large, complex organizations-both public and private" (Collier, 1979, p. 403). Expertise is the crucial attribute that technocrats exploit to legitimize themselves as objective public servants, immune to ideological biases. Of course, we know well that expertise claims can be used to downplay quite strong ideological biases, but, in political discourse, these policies are presented as objective and neutral.

From these definitions, we can derive at least two potential sources of conflict with technocrats built into the very concept of a populist politician. First, populists in power tend to have a fragile political coalition made up of politicians glued together only by their opposition to the establishment. This same anti-establishment stance usually prevents Latin American populists from making alliances with existing parties to secure their grasp on power. Hence, populists rely to a much larger extent on popular support than non-populist politicians to keep members of their party in check and their adversaries at bay, which makes them particularly wary of advice that could harm their approval numbers and their potential pool of voters. Consequently, economic technocrats, who under certain circumstances may advocate unpopular yet 'economically sound' measures, can be uncomfortable partners for populists.

Second, the outsider status of the prototypical populists and their anti-establishment appeals are sources of tension with technocrats. On the one hand, given their outsider status, populists do not have the necessary networks to recruit or trust experts with government experience. On the other hand, and especially when people perceive experts as closely tied to the establishment that populists rallied against, breaking with experts, it can be a signalling mechanism to voters that populists are serious about their intentions to punish said establishment and take their country in a different direction.

Although undoubtedly there are good historical examples that confirm this tension, in this article we propose that the relationship between economic technocrats and populists is less conflictive than usually assumed and cohabitation a more common outcome than expected. We argue that two conditions moderate conflict between populists and economic technocrats, leading not only to their cohabitation but to cooperation between them: the programmatic mandate of populists and the economic context of their rise to power. This does not mean that populists will not have other tensions with technocrats in different policy areas (health, commerce, environment, integration), but points to certain fundamental limits to populist power regarding economic management.

The next section explains the logic by which we claim these two conditions change the incentive structure and the resources available for populists to act in confrontation with economic technocrats. Section 3, the article's core, analyses the relations of economic experts with nine populist presidents in contemporary Latin America to show the soundness of this argument. We conclude discussing the limitations and implications of our main assertions. 


\section{The Political Economy of Populist and Technocratic Relations}

In this article, we claim that populists and economic technocrats can cooperate, cohabitate, or be in conflict. By s'cooperation,' we mean that populists and technocrats will have a close relationship that will grant the latter significant leeway and power to shape public policy in economic issues. In situations of 'cohabitation,' populists will neither empower nor give autonomy to economic technocrats, but will not remove them from office, and will respect the budgetary limits adopted by finance ministries. Finally, 'conflict' refers to instances when populists remove economic technocrats from their positions, personalize economic decision-making, and appoint loyalists with little experience or credentials, and hence less autonomy vis-à-vis the President.

What makes populists and technocrats engage in these different dynamics? The first condition to consider is the nature of the populist leader's programmatic mandate. Although populism in Latin America since the times of Juan Peron and Getulio Vargas has been associated with redistributive leaders, the advent of populists who implemented a 'neoliberal' and security-centred program during the 1990s made clear that right-wing leaders can use similar mobilization strategies and discourses as those used by 'classic' populists (Roberts, 1995; Weyland, 1996, 1999). Furthermore, recent developments in the literature that consider populism as an ideological phenomenon in itself, also recognize its capacity to work through different "host ideologies" (Colodro, Cachafeiro, \& Marné, 2018; Huber \& Ruth, 2017; Huber \& Schimpf, 2017; Mudde, 2004; Mudde \& Rovira Kaltwasser, 2013).

In this article, we do not focus on the ideology as an attribute of populist leaders but on their mandate. Some populist politicians will have a more defined ideological profile than others, but all populists who rise to power do so in a context that binds them to a mandate. Their ascent is usually preceded by some kind of crisis and the convergence on the part of established parties around a similar programmatic position to confront it, blurring the differences between them and leaving an opening for populist challengers to outflank them from the right or left (Lupu, 2016; Roberts, 2015; Slater \& Simmons, 2013; Weyland, 2002). Hence, the nature of the crisis, and the choices made by established parties to confront it, shape the kind of mandate populists are likely to be given when voted into office.

We propose that programmatic mandates are vital because they shape the voting base and the core constituency that will support populists in power. In turn, these introduce different incentive structures for populists to break with economic technocrats. Populists with a right-wing mandate build their relationship with their voters over issues that are not related to distributive policies, precisely because the crises that they rise from are related to security deficiencies or severe econom- ic mismanagement. Their core constituency, a concept which refers to the social sectors that are the most important for a party's political agenda and resource mobilization (Gibson, 1996), is composed of economic elites and external actors such as foreign investors or multilateral agencies, which provide them with the stability and resources needed to remain in power. As a consequence, they are more likely to cooperate with economic technocrats. The populist base will not reject them as fiercely, and their presence will signal to the constituency that their interests will be protected.

Unlike right-wing populists, who in the region usually rise to power in the context of a security crisis, those with left-wing mandates ride the waves of economic discontent that hit the lower-income groups hardest. Since these populists accumulate support on the promise to end the historical and structural economic injustices that are characteristic of Latin America (Weyland, 2013), lower classes are more amenable to become their most significant supporters.

A lower-class coalition and a redistributive agenda, however, does not preclude them from working alongside technocrats. It is their need to swiftly fulfil this promise, which leads to a push for a quick and vast expansion in spending and hence puts them on a path of conflict with economic technocrats. Furthermore, their core constituency is typically composed of organizations such as labour unions and local industrialists, who seek targeted benefits and protections, and who are usually conceived as 'rent-seekers' by economic technocrats. Hence, voters and key constituencies will produce more tension between economic technocrats and populists with a redistributive mandate, leading to conflict.

This inclination to conflict, however, is moderated by contextual restrictions on spending. Being part of what dependency theorists called 'the periphery,' Latin American economies are heavily conditioned by developments in industrialized countries. The booms and busts in commodity prices usually play the role in enabling and disabling the conditions for the state to be able to quickly attend to redistributive demands and thus affect populists' political opportunities (Weyland, 2020). Crises that follow from commodity busts often lead to the appointment of technocrats or support their continuity. This pattern, by which economic crises lead to technical appointments, has been observed in Argentina, Bolivia, Brazil, México, and Peru at times in the late 1980s and early 1990s (Kaplan, 2013, pp. 53-54; Teichman, 1997, 2004; Weyland, 2002). Adverse economic conditions will limit populists' capacity to discard experts and lead to what we call 'cohabitation' between left-wing populists and economic technocrats.

Economic booms, on the other hand, lead to conflict by enabling left-wing populists and allow them to fire economic technocrats. This does not mean that the relation between right-wing populists and experts will not be affected by economic booms. As discussed later, a change to more positive external economic condi- 
tions can augment tensions between right-wing leaders and experts. Nevertheless, while left-wing populists use this opening to dismantle technocracy, those on the right will not be as aggressive. Unlike left-wing populists, rightwing populists' mandates do not push them to implement redistributive measures or set them in a path of confrontation with economic elites. Hence, the international economic context plays a role in enabling or disabling populist's inclination to enter into conflict with economic technocrats.

We summarize the expected outcomes of the relationship between populism, programmatic mandate, and the global economic environment in Figure 1.

We present this argument by analysing the relationship between nine populist presidents and economic technocrats in contemporary Latin America. Two criteria, one temporal and the other spatial, guided this selection. First, we selected populism cases starting in the era of market reforms in the region during the late 1980s. This timeframe gives us a period with significant variation in the programmatic mandate populists received and the kind of international economic environment they confronted. Additionally, economic technocrats became a more salient feature of the region during these decades than during the first half of the twentieth century, when classic populism took hold.

Second, we limit ourselves to cases within South America, which is our regional expertise. This choice excludes other potential cases such as those of Daniel Ortega in Nicaragua, Manuel Zelaya in Honduras, Mireya Moscoso in Panamá, or Hipólito Mejía in the Dominican Republic. Given that the empirical support for our argument comes mainly from within-case evidence rather than from large- $\mathrm{N}$ correlational analysis, regional expertise was an important criterion for case selection. Empirically, our conclusions are thus limited to South America. Theoretically, however, there is nothing about our argument that prevents it from 'travelling' and being tested beyond this subregion.

From the scope of cases within these criteria, we excluded two populists, both from Ecuador. Abdalá Bucaram (1996-1997) ruled for less than six months, and hence it is not possible to distinguish a clear governing pattern in that timeframe. The second exclusion, Rafael Correa's administration, has been labelled as a case of "technocratic populism" by authors such as de la Torre (2013). By this term, he refers to the combination of a populist discourse and a governing logic that bases the legitimacy of its actions on the technocratic credentials of its leader. However, this article does not study technocratic populism, but the coexistence of technocrats and populists in government. Since Correa embodies both of these actors in power, it is impossible to think of a counterfactual scenario in which the populist and the technocratic orientations do not coexist, making it an irrelevant case for empirical testing.

The cases exhibit variation in the programmatic mandate and on the international economic environment in which they governed. Carlos Ménem in Argentina (1989-1999), Alberto Fujimori (1990-2000) in Peru, Fernando Collor de Mello in Brazil (1990-1992), and Alvaro Uribe (2002-2010) in Colombia are four cases of right-wing mandates. Among our five cases of left-wing populists, three rose to power during stringent economic conditions. Lucio Gutierrez (2002-2005) in Ecuador ruled during a financial duress period and cohabitated with technocrats during his term. Hugo Chávez (1999-2013) in Venezuela and Néstor Kirchner (2003-2007) in Argentina eventually enjoyed the benefits of a commodity boom, leading to conflict with experts. Finally, in Argentina, Cristina Fernández (2007-2015) initiated her rule during a period of few budgetary constraints, as did Evo Morales (2006-2019) in Bolivia.

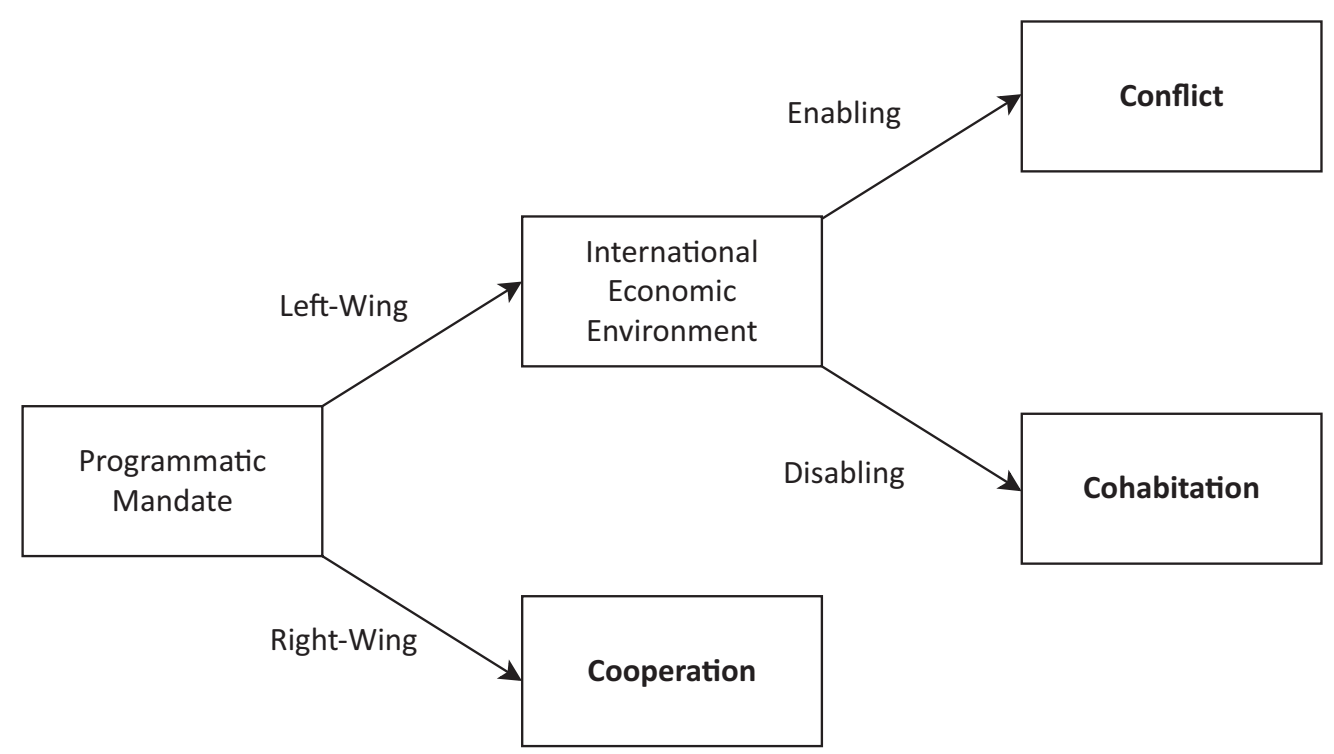

Figure 1. Conditions affecting populists and economic technocrats' relationships and their expected outcomes. 
Table 1 presents the different cases considered, as well as their expected outcomes. Although we consider nine presidents, we analyse 11 cases, as some of these presidencies divide into two periods to capture the variation of the international economic environment throughout their tenure. We code these populist presidencies in terms of their programmatic mandate and of the international economic environment they confronted. Ten of the 11 cases fit our prediction, the exception being the case of Bolivian President Evo Morales. We will use this case as it is an opportunity to highlight some additional domestic factors that can affect the relationship between experts and populists, which we believe account for why this case did not fit our expected outcome.

\section{Cooperation: Right-Wing Populists and Technocrats}

The cases of the right-wing populists Álvaro Uribe in Colombia, Alberto Fujimori in Peru, Collor de Mello in Brazil, and Carlos Ménem in Argentina illustrate the higher likelihood of cooperation between experts and populists. In all cases, experts were fundamental to signal these populists' economic prudence to the right-wings' ruling coalitions.

Alvaro Uribe broke with the Liberal Party to run as an independent in the 2002 election. Uribe sharply criticized the weak stance of the two traditional-and until then dominant-parties (Liberals and Conservatives) against guerrilla groups. The failure of a peace process led by a Conservative president deepened the fracture of citizens from their political elite. This crisis delegitimized both parties and allowed Uribe to win the Presidency with a securitization agenda and a strong anti-leftist rhetoric (Gutiérrez, 2006). Lacking a political party and running on an anti-establishment ticket, Uribe built alliances with other independent politicians and sought to secure a large voting coalition that would allow him to rule with little need for partisan negotiations (Dugas, 2003). Although there was no acute economic crisis in Colombia at the time of his election, Uribe quickly assured business actors that he would guarantee economic stability and fiscal prudence, enhancing his support.

Some authors, such as Dugas (2003), do not consider Uribe a populist, mainly due to his lack of charisma. We do not deem charisma a defining feature of populism, and Uribe's behaviour during the electoral campaign and administration fits our definition. As mentioned, he presented himself as an outsider challenging the political establishment, railing against 'politiquería' in the country, and used public support to defy limits imposed by liberal institutions.

Throughout his two terms in office (2002-2006; 2006-2010), Uribe respected the five-decade-long Colombian tradition of appointing experts in the Ministry of Finance and the National Planning Department, even when he was popular enough to break it with few consequences. Although he increased some social programs that reinforced his close relationship with the citizenry, leading to some public clashes with his finance ministers, in general Uribe was very careful to show that he accepted technocratic oversight and that he was committed to prudent economic management (Dargent, 2015, Chapter 4). These measures guaranteed him support, albeit sometimes unenthusiastic, from business and international actors.

In 1990, Peru faced a double crisis: a hyperinflationary economy and an internal war against the Shining Path, a Maoist guerrilla organization. Fujimori, a complete outsider, won that year's election by surprise partly due to the delegitimization of political parties. His mandate was not originally right-wing. On the contrary, what took him to the Presidency in the second round of the election were the votes of leftists and centrists opposed to the radical market liberalization program proposed by his right-wing opponent, novelist Mario Vargas Llosa. Nonetheless, immediately after winning, Fujimori moved to the right as he realized he needed a right-wing core constituency to stabilize his grasp on power. First, International Financial Institutions (IFIs) conditioned any

Table 1. Cases, moderating conditions, and expected outcomes.

\begin{tabular}{lcccc}
\hline & \multicolumn{2}{c}{ Moderating Conditions } & \multicolumn{2}{c}{ Outcomes } \\
\cline { 2 - 5 } Cases & $\begin{array}{c}\text { Programmatic } \\
\text { Mandate }\end{array}$ & $\begin{array}{c}\text { International Economic } \\
\text { Environment }\end{array}$ & Expected & Actual \\
\hline Carlos Ménem (1989-1999) & Right-Wing & Disabling & Cooperation & Cooperation \\
Alberto Fujimori (1990-2000) & Right-Wing & Disabling & Cooperation & Cooperation \\
Álvaro Uribe (2002-2010) & Right-Wing & Enabling & Cooperation & Cooperation \\
Fernando Collor de Mello (1990-1992) & Right-Wing & Disabling & Cooperation & Cooperation \\
Hugo Chávez (1999-2003) & Left-Wing & Disabling & Cohabitation & Cohabitation \\
N. Kirchner (2003-2005) & Left-Wing & Disabling & Cohabitation & Cohabitation \\
Lucio Gutierrez (2003-2005) & Left-Wing & Disabling & Cohabitation & Cohabitation \\
N. Kirchner (2005-2007) & Left-Wing & Enabling & Conflict & Conflict \\
Hugo Chávez (2004-2013) & Left-Wing & Enabling & Conflict & Conflict \\
Cristina Fernández (2007-2015) & Left-Wing & Enabling & Conflict & Conflict \\
Evo Morales (2006-2019) & Left-Wing & Enabling & Conflict & Cohabitation \\
\hline
\end{tabular}


external loan to the adoption of market reforms and shock treatment. Second, Fujimori aligned with the military to confront the Shining Path and adopted hard-line securitization rhetoric. Fujimori blamed traditional parties for the economic disaster and the failed war against terrorism. In 1992, the President closed Congress in a self-coup and increased his popularity while solidifying the support of business actors and the military. Following international pressure from IFls and the Organization of American States, Fujimori organized elections in which he won a congressional majority and solidified his power. In 1995, he won the Presidency with $64 \%$ of the vote, a result not previously seen in the first electoral round in Peru (Weyland, 1996, 2002).

Fujimori relied on orthodox economic experts to initiate profound market reforms that drastically changed the Peruvian state structure. During most of his two administrations (and some months into his third and unconstitutional term), Fujimori appointed experts in the Ministry of Economics and Finance (MEF). They were widely seen as a guarantee of economic stability for businesses and voters who had been traumatised by financial mismanagement. Additionally, officers influenced by securitization doctrines of the autocracies of the Southern Cone dominated the Armed Forces. Interestingly, the President and some of his military allies had little orthodox economic convictions. Nonetheless, they accepted MEF restrictions, understanding that business' and IFI's support were crucial for their stability (Dargent, 2015, Chapter 5).

Fernando Collor de Mello was elected President of Brazil in 1989 after a meteoric ascent in the polls. He had come to power as an outsider, distancing himself from Brazilian political parties, and promising to end the corruption enabled by the political establishment. The souring of public opinion against the political system came as a result of corruption scandals, meagre economic growth, and economic mismanagement that resulted in hyperinflation (Weyland, 1993). This crisis not only produced the conditions for the rise of an outsider like Collor but also generated a widespread consensus around the need for drastic measures to reform the Brazilian economy and change the development strategy, including austerity measures (Schneider, 1991).

Upon taking office, Collor de Mello appointed Zélia Cardoso de Mello, an economics professor, as finance minister. She was in charge of overseeing the implementation of the New Brazil Plan, a set of policies designed to curb inflation, which became known as the 'Plan Collor.' As many stabilization policy packages around the region at that time, the plan included privatizations, reductions in public employment, and the elimination of subsidies to public utilities. Economic reform plans were conducted with significant autonomy and even isolation from political forces. In this sense, Collor not only cohabitated with economic technocrats, their relationship was one of cooperation. It was partly the exclusive reliance on economic technocrats that led to the erosion of Collor's political and social support coalition and the inability of the government to get the labour and business sectors to cooperate with the government (Schneider, 1991). It was this isolation that eventually laid the ground for Collor's fall. After his plans to turn the Brazilian economy around failed, and without allies or popular support on his side, he resigned in December of 1992 before Congress voted for his removal from office, amid accusations of corruption.

Finally, Carlos Ménem (1989-1999) also exemplifies the tendency among populists with a right-wing mandate to cooperate with technocrats. Menem won the Presidency as the Justicialista Party candidate, a political organization associated with Peronismo, which in the history of Argentina has usually meant left-wing redistributive policies. Nonetheless, Menem reached power with the electoral mandate to end the hyperinflationary crisis that had caused a premature ending of his predecessor's government (Weyland, 2002). After some initial failures to end the crisis, in 1991 Menem appointed Domingo Cavallo, a neoliberal technocrat, as Economic Minister. Cavallo adopted an ambitious market reform to stop inflation and privatize public enterprises. Privatization allowed Menem to build a support coalition with business sectors while weakening the support of more traditional Peronist rival leaderships (Weyland, 2003, p. 1100). The government successfully reduced inflation, which gave Menem the political space to reform the Constitution to allow re-election for one term (although reducing presidential terms from six years to four). This technocratic guidance of macroeconomic policy did not prevent Menem from using clientelistic strategies to build alliances and win electoral support. In 1995, Menem won re-election with $49.9 \%$ of the vote, 20 points over his closest rival.

After winning re-election, Menem continued his collaboration with Cavallo. New economic problems lead to a change in the Ministry of Economics in 1996, but Cavallo's replacement, Roque Fernández, was also a neoliberal technocrat who achieved similar influence and stability. Fernández kept the position until the end of Menem's government.

In sum, right-wing populists, due to their original mandate and the nature of their coalitions, have fewer incentives to clash with technocrats. As discussed later for the case of Fujimori, the change in economic conditions can lead to some tension between Presidents and experts, but usually not to conflict.

\section{Cohabitation: Left-Wing Populists, Resource Scarcity, and Technocrats}

As mentioned, left-wing populists win elections with a mandate to subvert political orders perceived as unjust and exclusionary. Economic duress attributed to the failed stabilization plans of right-wing governments and the convergence by traditionally left-wing parties on these policies create the opening for leftist leaders to 
reach power. Nonetheless, the international environment moderates this conflict. Reaching power under conditions of economic duress will make populists more cautious in their handling of the economy and more likely to cohabitate with experts to signal financial responsibility. This support will not be enthusiastic, and we can expect more clashes than in the previous cases, but toleration is more likely than conflict.

Three of our five leftist leaders faced this economic restraint. The late 1990s propelled left-wing populists to power and limited their capacity to fulfil the promise of redistribution once in office. Hugo Chávez, Lucio Gutierrez, and Néstor Kirchner all won the Presidency with distributive mandates, and all of them, initially, appointed experts in their ministries of finance. While Gutierrez was never able to break this cohabitation, Chávez and Kirchner eventually fired experts to appoint loyalists.

In Ecuador, Lucio Gutierrez won the 2002 presidential election on an anti-establishment platform and, in alliance with movements and parties to the left of the political spectrum, promised to put an end to austerity policies and increase social protection. The country, albeit inconsistently (Pachano, 2007), had implemented market-oriented reforms in the previous decade and then faced an economic crisis that put the country in a recession.

This scenario made Gutierrez's ascent to power more likely, but also made it more challenging to keep his promises once in office. Gutierrez tried to keep his populist coalition in place by pushing an 'anti-corruption' agenda that sought to signal his commitment to punish political and economic elites, and he switched to austerity policies in the financial realm. Upon taking office, Gutierrez named Mauricio Pozo as finance minister. Pozo, an economist from the University of Notre Dame, at the time, had a decade of experience at Ecuador's Central Bank. Soon after that, his administration signed an agreement with the IMF to receive financial support. Gutierrez's allies on the left saw this as a sign of a plot by elite 'techno-bureaucrats' rooted in the state apparatus, with links to the international and private financial sectors (Buendía, 2004, pp. 71-72).

Three months after assuming office, Gutierrez explained the rationale behind his decisions. He argued the economic crisis left little room for redistributive policies, emphasizing the need to cut spending and recover the country's credibility vis-à-vis foreign investors and international organizations, which became key actors for a country in search of relief ("Entrevista con el Presidente Constitucional", 2003). Gutierrez, however, did not last long in power. After being unable to secure a strong coalition to support him, he abandoned the Presidency and left the country in 2005 amid a popular revolt against his Presidency.

Chávez's stance against technocratic elites was rooted in the mandate upon which he was elected into office. Amid a prolonged economic crisis and a series of cor- ruption scandals that eroded voters' trust in established parties, Chavez came to power railing against them and claiming that power needed to be taken away from political and technocratic elites and given back to the people' (Hawkins, 2010). However, the replacement of technocrats with loyalists was not immediate, nor was it without setbacks. Upon taking office, Chávez decided to leave Maritza Izaguirre, an appointee of his predecessor in power, in charge of the Finance Ministry. Chávez had come to the office during one of the worst economic crises the country had ever experienced. Oil, the government's most important revenue source, was at US \$9 per barrel in 1998, down from the US \$29 it had enjoyed in 1981.

Consequently, the government initially focused on fiscal adjustment and provided international investors with guarantees of contract stability and the possibility of international arbitration of disputes (Corrales \& Penfold-Becerra, 2011, p. 51). Izaguirre's appointment was meant to signal to creditors and economic agents that the administration sought to maintain some stability amid low economic performance and uncertainty surrounding Chávez's new direction (Kelly \& Palma, 2004, p. 218). The same crisis that had helped propel Chávez to power also constrained him from breaking with the past.

Six months after taking office, and with signs of a recovering economy, Chávez removed Izaguirre from the Ministry of Finance. He appointed three different finance ministers between late 1999 and early 2002: José Rojas, Nelson Merentes, and Francisco Usón. Rojas was a low-level bureaucrat before Chávez's Presidency, and Merentes a mathematician who was also a member of the National Tactical Command of Chávez's party, the MVR (Weyland, 2001, p. 81). Usón, for his part, was a retired general, part of the coalition of military and former military that had joined the new administration.

However, this attempt to break with economic experts would not last, as the performance of the economy was still irregular, and domestic turmoil had again pushed the country into recession. In early 2002, Chávez appointed a University of Chicago-trained economist, Felipe Pérez Martí, to the Ministry of Planning. Similarly, Usón was replaced as the finance minister by Tobias Nóbrega, an economist and a professor at the Universidad Central de Venezuela and the Universidad Andres Bello. The changes aimed at seeking a way out of the severe economic crisis that was consuming the country (Vera, 2015, p. 546). Part of the new policy package that Pérez and Nóbrega put forward included new taxes and slashes to the national budget. Upon announcing the new measures to the nation, Pérez highlighted the critical condition of the economy, and that these initiatives were consulted with domestic and foreign specialists ("Venezuela anuncia medidas económicas," 2002).

Néstor Kirchner won the 2003 Argentinean election with a clear leftist mandate. There were doubts about how Kirchner would handle the economy, but, as President, he cohabitated with experts during his first year. To understand this outcome, one has to look back 
at the antecedents and the effects of the 1999 financial crisis in Argentina.

Orthodox economic technocrats had dominated the Ministry of Finance throughout the 1990s. These experts were associated with neoliberal reforms, which stopped the country's hyperinflationary crisis. When orthodox economists were blamed for the 1999 financial crisis, their prestige was severely weakened. The crisis not only profoundly affected the popularity of outgoing President Carlos Ménem (1989-1999) but also ended up with the Presidency of Fernando de la Rúa when he was forced to resign due to his insistence on orthodox measures to control the crisis (1999-2001; Weyland, 2002, pp. 202-204).

After several presidents appointed by Congress resigned in the following weeks, Eduardo Duhalde was able to achieve some stability upon taking office in January 2002 and finish De la Rua's term. Duhalde appointed the heterodox economist Roberto Lavagna as Minister of Economics. Lavagna modified some orthodox policies while maintaining prudent economic management (Panizza, 2014, p. 33).

As a sign of commitment to economic stability, incoming President Néstor Kirchner (2003-2007) maintained Lavagna in his position. Nonetheless, when the crisis receded and Kirchner achieved a landslide victory in the November 2005 legislative elections, the President asked for Lavagna's resignation. According to Kaplan, Kirchner behaved more cautiously than Chávez due to the fear of a hyperinflationary crisis due to a traumatic crisis in Argentina's recent history, but he still fired heterodox experts and increased funding for his support coalition (Kaplan, 2013, pp. 3-5).

Concluding, experts and populists' cohabitation is even possible when left-wing populists are constrained by international conditions, as the previous cases show. The tension between populists and technocrats can emerge and lead to conflict. We turn in the last section to analyse this relation.

\section{Conflict: Left-Wing Populists, Resource Abundance, and Technocrats}

As discussed earlier, when the international economic context is propitious, there is a higher possibility of conflict between experts and populists. Both the cases of Hugo Chavez and Nestor Kirchner and the continuity of populism under Cristina Fernández show the higher likelihood of conflict introduced by this condition.

The previous section showed how Chávez could not immediately break with economic experts. However, he eventually did. During his tenure, inflation remained among the highest in the region, going from an annual rate of $35.8 \%$ when he took office in 1999 to $40.6 \%$ in 2013 when he passed away, and then climbing to $65,000 \%$ in 2018.

Pérez Martí was removed from the Ministry of Planning in April 2003. According to him, his marketfriendly policies lost the President's support following the strike by oil workers and managers of Petróleos de Venezuela S.A., after which hard-line positions made gains within his administration (Barráez, 2019). These changes coincided with a significant shift in the international scenario. The invasion of Iraq by the US in March of 2003 and the rise of China and India would contribute to a surge in oil prices starting in 2003. Nobrega left the finance ministry in December of 2004, amid reports of months of discomfort with the government's direction (Webb-Vidal, 2004). From then on, Chávez's government would run large deficits and maintain an overvalued exchange rate, planting the seed for the future economic collapse and hyperinflation. Later, Pérez Marti would point at the booming oil prices as the primary reason why the government could sustain these policies and avoid the consequences, which were made evident once oil prices went down again after Chávez's death in 2013 (Pérez Martí, 2013).

As mentioned, once the economy had favourable international conditions and achieved a stronger political coalition in the 2005 legislative elections, Néstor Kirchner stopped accepting the limits imposed by economic experts. Kirchner personalized economic decisionmaking and reduced technical capacity in financial institutions. From then on, his finance ministers were mostly loyalists. Cristina Fernandez de Kirchner succeeded her husband and maintained his coalition, further moving it to the left and increasing personalistic economic management. During her administration, these tendencies radicalized as the international context remained propitious (Kaplan, 2013, pp. 3-4; Redrado, 2010).

Interestingly, in both cases, Argentina and Venezuela, we see that a return to technocratic rule did not happen when economic conditions worsened. Deteriorating conditions did not move Chavez or Kirchner back to technocratic cohabitation or cooperation. As we point out in the conclusion, it seems that once the cohabitation between left-wing populists and technocrats is broken, reconciliation seems unlikely. The risk of weakening a political coalition dependent on public funds, especially in what are likely to be difficult political times, makes populists maintain their grip over economic policy.

Right-wing populists, on the other hand, usually remain within technocratic cooperation or, at most, move towards cohabitation, even under favourable economic conditions. In 1999, under more favourable economic conditions and while seeking a third-and unconstitutional-term, Fujimori fired his orthodox Minister of Finance, Jorge Camet, and appointed a loyalist without similar economic credentials, Víctor Joy Way. Nevertheless, he did keep other technocrats within the ministry in place and later that same year, when the 1999 financial crisis hit Peru, Fujimori moved back to full cooperation.

To conclude, we discuss the case of leftist populist Evo Morales (2006-2019) to explain why we believe it does not fit our model's expected outcome. According to our model, Morales should have had a conflictive 
relationship with economic technocrats. Nonetheless, on macroeconomic matters, Morales respected technicaleconomic guidance. His finance minister, Luis Arce, kept the position during almost all of Morales' Tenure (January 2006-June 2017; January 2019-November 2019).

In this case, we believe, cohabitation is rooted in two factors: hyperinflationary taboos and personal linkages. First, Kaplan (2018) highlights how previous crises in the 1980s increased the perceived political costs of hyperinflation and prevented the personalization and deprofessionalization of management at the Ministry of Finance. Arce's presence signalled economic prudence towards elites and citizens. Second, in this case, there is a relevant factor which is quite difficult to generalize: personal linkages. Morales was known for building strong relationships of trust with some of his collaborators, Arce being one of them. This personal trust is illustrated by the fact that, after leaving office in 2019 amid a popular uprising and a soft military coup d'état, Morales handpicked Arce as his successor to run for the Presidency under the Movimiento al Socialismo ticket in 2020.

\section{Conclusion}

In this brief piece, we have presented two main ideas about populists and their relationship with experts. First, even if seen as inimical, there are a variety of instances in which populists cohabitate and even cooperate with technocrats. Populists with right-wing mandates have fewer incentives to clash with experts, as economic technocrats can be quite useful for signalling commitment to prudent economic policy to their governing coalitions. Moreover, even in the case of left-wing populists with redistributive mandates, the international context will moderate the tension between these actors. The first conclusion of the article is that experts and populists are not inherently at odds.

A second closely related idea is that these findings question descriptions of populists as ideological zealots, capable of breaking all limits no matter the consequences. Dependent on their support coalitions and international economic conditions, we find a more rational and calculating political actor than expected, even in the case of left-wing actors with a mandate for swift redistribution. The irrational profligate populist seems more a result of favourable international economic conditions permitting high levels of spending than of ideological commitments. Once leftist populists break up with experts and build distributive support coalitions, it seems quite difficult for them to reappoint technical ministers and move back into economic prudence without risking the support of these coalitions. Some pathdependence mechanisms seem to be at work, but laying them out with precision would require further research.

Finally, the case of Evo Morales shows that the two conditions that we identify are not the only ones affecting the relationship between technocrats and populists. Other domestic and, to some extent, idiosyncratic factors can play a role as well. Beyond Morales' personal trust in his finance minister, recent memory of an economic collapse, such as a hyperinflation crisis, will make elites and voters aware that profligate spending can open the door to new crises (Kaplan, 2013, 2018). Economic experts can be perceived as a signal to elites and citizens of responsible economic policy, thus increasing the cost of firing them (Dargent, 2015).

However, this barrier does not seem to be insurmountable. The Argentinian cases prove that, although memories of past inflationary crises can moderate populists' handling of the economy, under favourable international economic conditions Kirchner and Fernández relaxed constraints over public deficits and discarded technocrats. Although Morales' exception is worth noting and explaining, we think programmatic mandates and the international economic context have significant power in explaining the relationship between economic technocrats and populists in Latin America.

Lastly, our analysis can have implications for other realms of public policy under populist administrations. In the context of the Covid-19 pandemic, cases of conflict between populists and health experts, such as those seen in Trump and Bolsonaro's administration in the US and Brazil, have sparked questions about the relationship between populist presidents and willingness to listen to science. The experience with economic experts reveals that populists are more willing to do so when it does not clash with the fulfilment of their mandate or when they face significant restrictions on their governing options in the absence of experts. This experience suggests that, rather than looking at populists' response to the pandemic as ideologically driven, research on this subject should focus on how the incentives and restrictions in place condition their policy response to the virus. Ultimately, this means focusing on what kinds of sentiments and demands brought them to power and the strength of the social and political coalitions around health experts vis-à-vis those supporting populists in power.

\section{Acknowledgments}

Rodrigo Barrenechea would like to thank the Weatherhead Center for International Affairs, at Harvard University, for hosting him as a Postdoctoral Fellow in the Research Cluster on Challenges to Democracy while he worked on this article. Eduardo Dargent would like to thank the Pontifical Catholic University of Peru for a sabbatical semester in 2019.

\section{Conflict of Interests}

The authors declare no conflict of interests.

\section{References}

Acemoglu, D., Egorov, G., \& Sonin, K. (2013). A political theory of populism. The Quarterly Journal of Eco- 
nomics, 128(2), 771-805. https://doi.org/10.1093/ qje/qjs077

Barráez, S. (2019, November 4). Felipe Pérez Martí, el ex funcionario de Hugo Chávez que vaticina "una asonada militar con apoyo internacional y popular" para liberar a Venezuela [Felipe Pérez Martí, the former Chavista official who foresees "a military coup with international and popular support" to free Venezuela]. infobae. Retrieved from https://www. infobae.com/america/venezuela/2019/11/04/felipeperez-marti-el-ex-funcionario-de-hugo-chavezque-promueve-una-asonada-militar-con-apoyointernacional-y-popular-para-liberar-a-venezuela

Buendía, F. (2004). La resistencia empezó en la economía [The backlash started in the economy]. In A. Barrera (Eds.), Entre la utopía y el desencanto: Pachakutik en el gobierno de Gutiérrez [Between utopia and disenchantment: Pachakutik in the Gutiérrez's administration] (pp. 61-95). Quito: Planeta.

Buštíková, L., \& Guasti, P. (2019). The state as a firm: Understanding the autocratic roots of technocratic populism. East European Politics and Societies, 33(2), 302-330. https://doi.org/10.1177/ 0888325418791723

Caramani, D. (2017). Will vs. reason: The populist and technocratic forms of political representation and their critique to party government. American Political Science Review, 111(1), 54-67. https://doi.org/ 10.1017/S0003055416000538

Centeno, M. A., \& Silva, P. (1998). The politics of expertise in Latin America: Introduction. In M. A. Centeno \& P. Silva (Eds.), The politics of expertise in Latin America (pp. 1-12). London: Palgrave Macmillan UK. https://doi.org/10.1007/978-1-349-26185-7_1

Collier, D. (1979). Glossary. In D. Collier (Ed.), The new authoritarianism in Latin America (pp. 399-404). Princeton, NJ: Princeton University Press.

Colodro, C. P., Cachafeiro, M. G.-R., \& Marné, H. M. (2018). Does host ideology shape populist parties' attitudes towards the EU? The links of populism and Euroscepticism in Southern Europe. Revista Internacional de Sociología, 76(4). https://doi.org/10.3989/ ris.2018.76.4.18.003

Corrales, J., \& Penfold-Becerra, M. (2011). Dragon in the tropics: Hugo Chavez and the political economy of revolution in Venezuela. Washington, DC: Brookings Institution Press.

Dargent, E. (2015). Technocracy and democracy in Latin America. Cambridge: Cambridge University Press.

Dargent, E. (2020). Technocracy in Latin America: Between stability and democratic deficit. In E. Bertsou \& D. Caramani (Eds.), The technocratic challenge to democracy (pp. 216-231). Abingdon and New York, NY: Routledge.

de la Torre, C. (2013). Technocratic populism in Ecuador. Journal of Democracy, 24(3), 33-46. https://doi.org/ 10.1353/jod.2013.0047

Dornbusch, R., \& Edwards, S. (Eds.). (1991). The macroe- conomics of populism in Latin America. Chicago, IL: University of Chicago Press. Retrieved from https:// www.nber.org/books/dorn91-1

Dugas, J. C. (2003). The emergence of neopopulism in Colombia? The case of Álvaro Uribe. Third World Quarterly, 24(6), 1117-1136.

Entrevista con el Presidente Constitucional de la República del Ecuador, Lucio Gutierrez [Interview with the Constitutional President of the Republic of Ecuador, Lucio Gutierrez]. (2003, April 14). World Investment News. Retrieved from http://www.winne.com/ topinterviews/presidentgutierrez.html

Gibson, E. L. (1996). Class and conservative parties: Argentina in comparative perspective. Baltimore, MD: Johns Hopkins University Press.

Guasti, P., \& Buštíková, L. (2020). Varieties of technocratic populism around the world [Thematic Issue]. Politics and Governance, 8(4), 468-602.

Gutiérrez, F. (2006). ¿Más partidos? [More parties?]. In F. L. Buitrago (Ed.), En la encrucijada: Colombia en el siglo XXI [At the crossroads: Colombia in the 21st century] (pp. 147-170). Bogotá: Grupo Editorial Norma.

Hawkins, K. A. (2010). Venezuela's Chavismo and populism in comparative perspective (1st ed.). Camdrige: Cambridge University Press.

Huber, R. A., \& Ruth, S. P. (2017). Mind the gap! Populism, participation and representation in Europe. Swiss Political Science Review, 23(4), 462-484. https://doi. org/10.1111/spsr.12280

Huber, R. A., \& Schimpf, C. H. (2017). On the distinct effects of left-wing and right-wing populism on democratic quality. Politics and Governance, 5(4), 146-165. https://doi.org/10.17645/pag.v5i4.919

Kaplan, S. B. (2013). Globalization and austerity politics in Latin America. Cambridge: Cambridge University Press.

Kaplan, S. B. (2018). Fighting past economic wars: Crisis and austerity in Latin America. Latin American Research Review, 53(1), 19-37. https://doi.org/ 10.25222/larr.292

Kelly, J., \& Palma, P. A. (2004). The syndrome of economic decline and the quest for change. In J. McCoy \& D. Myers (Eds.), The unraveling of representative democracy in Venezuela (pp. 202-230). Baltimore, MD: Johns Hopkins University Press.

Levitsky, S., \& Loxton, J. (2013). Populism and competitive authoritarianism in the Andes. Democratization, 20(1), 107-136. https://doi.org/10.1080/13510347. 2013.738864

Lupu, N. (2016). Party brands in crisis: Partisanship, brand dilution, and the breakdown of political parties in Latin America. Cambridge: Cambridge University Press.

Mudde, C. (2004). The populist Zeitgeist. Government and Opposition, 39(4), 541-563. https://doi.org/ 10.1111/j.1477-7053.2004.00135.x

Mudde, C., \& Rovira Kaltwasser, C. (2013). Exclusionary vs. inclusionary populism: Comparing contemporary 
Europe and Latin America. Government and Opposition, 48(2), 147-174. https://doi.org/10.1017/gov. 2012.11

Pachano, S. (2007). La trama de Penélope: Procesos políti$\cos e$ instituciones en el Ecuador [Penelope's weft: Political processes and institutions in Ecuador]. Quito: FLACSO Ecuador-Agora Democrática.

Panizza, F. (2014). "Everybody out," "we are fantastic": The politics of financial crises in Argentina and Uruguay 2001-2003. In F. Panizza \& G. Philip (Eds.), Moments of truth: The politics of financial crises in comparative perspective (pp. 27-46). Abingdon: Routledge.

Pérez Martí, F. (2013, December 11). Guest post: How to avoid collapse in Venezuela. Financial Times. Retrieved from https://www.ft.com/content/ db89a0cc-c838-3d74-b9d6-03834b36b1d8

Redrado, M. (2010). Sin reservas: Un limite al poder absoluto [No reservations: A limit to absolute power]. Buenos Aires: Planeta.

Roberts, K. M. (1995). Neoliberalism and the transformation of populism in Latin America: The Peruvian case. World Politics, 48(1), 82-116. https://doi.org/ 10.1353/wp.1995.0004

Roberts, K. M. (2015). Changing course in Latin America: Party systems in the neoliberal era. Cambridge: Cambridge University Press.

Sachs, J. D. (1989). Social conflict and populist policies in Latin America (Working Paper No. 2897). Cambridge, MA: National Bureau of Economic Research. https:// doi.org/10.3386/w2897

Schneider, B. R. (1991). Brazil under Collor: Anatomy of a crisis. World Policy Journal, 8(2), 321-347.

Slater, D., \& Simmons, E. (2013). Coping by colluding: Political uncertainty and promiscuous powersharing in Indonesia and Bolivia. Comparative Political Studies, 46(11), 1366-1393. https://doi.org/ $10.1177 / 0010414012453447$

Teichman, J. (1997). Mexico and Argentina: Economic reform and technocratic decision making. Studies in Comparative International Development, 32(1), 31-55. https://doi.org/10.1007/BF02696305

Teichman, J. (2004). Merging the modern and the tradi- tional: Market reform in Chile and Argentina. Comparative Politics, 37(1), 23-40.

Venezuela anuncia medidas económicas [Venezuela announces economic measures]. (2002, May 30). BBC Mundo. Retrieved from http://news.bbc.co.uk/ hi/spanish/business/newsid_2017000/2017701.stm

Vera, L. (2015). Venezuela 1999-2014: Macro-policy, oil governance and economic performance. Comparative Economic Studies, 57(3), 539-568. https://doi. org/10.1057/ces.2015.13

Webb-Vidal, A. (2004, December 7). Venezuela politics: Venezuela dismisses finance minister. Financial Times. Retrieved from https://www.ft.com/content/ 88d76908-47e8-11d9-a0fd-00000e2511c8

Weyland, K. (1993). The rise and fall of President Collor and its impact on Brazilian democracy. Journal of Interamerican Studies and World Affairs, 35(1), 1-37. https://doi.org/10.2307/166101

Weyland, K. (1996). Neopopulism and neoliberalism in Latin America: Unexpected affinities. Studies in Comparative International Development, 31(3), 3-31. https://doi.org/10.1007/BF02738987

Weyland, K. (1999). Neoliberal populism in Latin America and Eastern Europe. Comparative Politics, 31(4), 379-401.

Weyland, K. (2001). Will Chavez lose his luster? Foreign Affairs, 80(6), 73-87.

Weyland, K. (2002). The politics of market reform in fragile democracies: Argentina, Brazil, Peru, and Venezuela. Princeton, NJ: Princeton University Press.

Weyland, K. (2003). Neopopulism and neoliberalism in Latin America: How much affinity? Third World Quarterly, 24(6), 1095-1115.

Weyland, K. (2013). The threat from the populist left. Journal of Democracy, 24, 18-32.

Weyland, K. (2020). Populism's threat to democracy: Comparative lessons for the United States. Perspectives on Politics, 18(2), 389-406. https://doi.org/ $10.1017 /$ S1537592719003955

Williams, M. E. (2006). Escaping the zero-sum scenario: Democracy versus technocracy in Latin America. Political Science Quarterly, 121(1), 119-139.

\section{About the Authors}
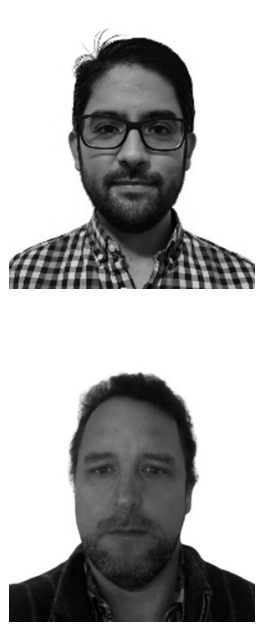

Rodrigo Barrenechea holds a PhD in Political Science from Northwestern. He was a Post-Doctoral Fellow in the Weatherhead Center Research Cluster on Challenges to Democracy, at Harvard University, during the 2019-2020 academic year. His research focuses on populism, political parties, and political representation in Latin America. His work has been published in the Oxford Handbook of Historical Institutionalism, Sociological Methods \& Research, British Journal of Sociology, and Quality \& Quantity: International Journal of Methodology. His main teaching and research interests are comparative public policy and democratization and the state in the developing world. He has published in Comparative Politics, the Journal of Latin American Studies, and the Journal of Politics in Latin America. His book Technocracy and Democracy in Latin America (Cambridge University Press) was published in 2015. 